\title{
Physics event photo analysis module based on the STEM approach: An effort to enhance critical thinking
}

\author{
Maryani $^{1}$, Yasmin Yuliana ${ }^{2}$, Firdha Kusuma Ayu Anggraeni ${ }^{3}$ \\ 1, 2, 3 Physics Education Department, Universitas Jember, Indonesia \\ *Corresponding Address: yasminyuliana23@gmail.com
}

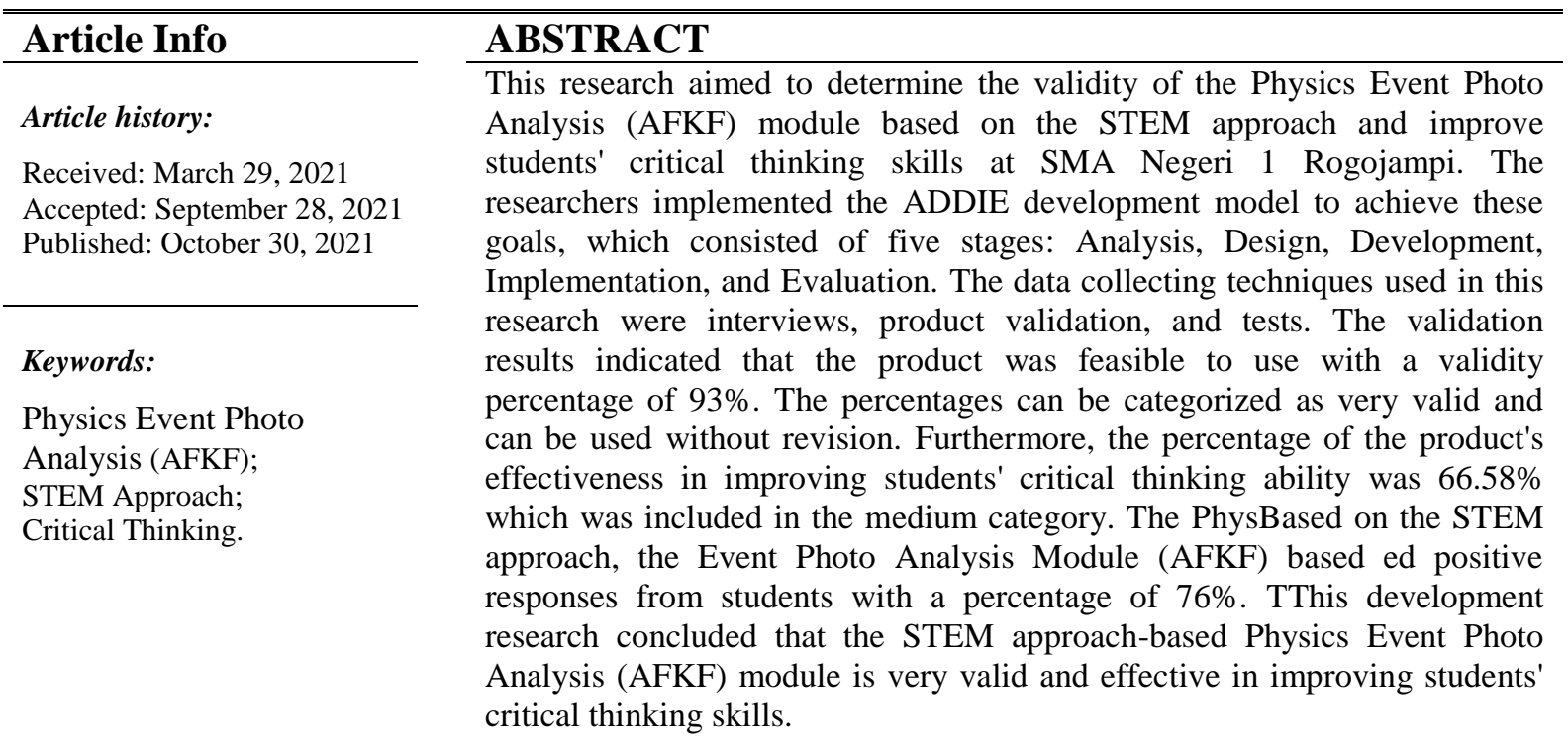

(C) 2021 Physics Education Department, UIN Raden Intan Lampung, Indonesia.

\section{INTRODUCTION}

Learning makes a person have an experience, mastery of character, skills, and attitudes (Suardi, 2018). Good science learning is to make students remember and understand theories from scientific findings and foster students' scientific attitudes and discover scientific concepts. Physics is one of the science branches (Natural Sciences), which also has the same essence. Therefore, besides studying the product, students must also master how to get the product in learning physics. The products of physics can be abstract and logical-mathematical, and physics knowledge. Abstract physics products are difficult to visualize, making it difficult for students to study abstract concepts. Physics contains many concepts, theories, or formulas that must be memorized and understood. If physics learning is associated with everyday life, students can easily understand it and apply it in everyday life according to their knowledge (Fouryza et al., 2019; Jeong \& Park, 2011; Rachmawati et al., 2017). Therefore, for physics learning to be more meaningful, learning is integrated with problems in everyday life.

Physics learning is learned contextually so it can be more meaningful (Broman et al., 2018; Sung et al., 2019; Tapingkae et al., 2020). Various contexts can support contextual physics learning. One used for contextual learning is usually the teacher using teaching materials in the form of modules. Prastowo (Fajarini, 2018) argues that the modules are arranged systematically in a language that is easy for students to apply, according to their age and level of knowledge, to learn independently with 
minimal guidance from the teachers. According to (Budi et al., 2018; Darma et al., 2019; Triyono (2021), the module is used as a means of independent learning. It has several objectives in supporting the learning process: to help students understand the material being studied, develop the abilities possessed by students, and encourage students to learn independently (Hidayati, 2018).

The module can improve scientific literacy (Maison \& Wahyuni, 2021), problem solving ability (Melvinasari \& Suparman, 2019), creative thinking skills (Rufaida \& Nurfadilah, 2021), and higher order thinking skills (Pane et al., 2021) However, Widyamurni's research (Sari et al., 2017) discovered that a learning module must optimize students' abilities to solve everyday life problems and improve critical thinking skills. Therefore, in this research, the developed teaching material was the AFKF module.

AFKF or Physics Event Photo Analysis is a study material in photos containing objects or events in everyday life that can be analyzed. Lin et al., (2017); Susilana \& Riyana (2009) argue that learning media in images will make learning more concrete. Therefore, the researchers used image media in photos following the theory by Riyana (2012). By analyzing photos of the physics events, students will remember the relevant concepts because they are focused on questions or problems that need to be solved using physics concepts. It is necessary to analyze physics events to trigger the development of students' thinking (Rachmawati et al., 2017). This Physics Event Photo Analysis (AFKF) module was developed based on the STEM approach.

The STEM (Science, Technology, Engineering, and Mathematics) approach can be integrated into the 2013 curriculum due to the increasingly competitive demands of an era. The 2013 curriculum must also be implemented in $21^{\text {st }}$-century learning, such as critical thinking, creativity, communication, and collaboration.
Handayani (Simarmata, et al., 2020) states that STEM is an approach formed based on a combination of several disciplines, namely Science, Technology, Engineering, and Mathematics. According to Lou et al., (2017), learning with the STEM approach helps students solve problems and helps students conclude learning by applying it through science, technology, engineering, and mathematics. This situation can increase students' interest in a more meaningful division and increase high-level skills (Lestari et al., 2018). Also, the STEM approach in learning enables students to acquire deeper knowledge and makes them more skilled in dealing with real-life problems in everyday life and developing students' critical thinking (Ardianti et al., 2020; Lestari \& Sumarti, 2018; Parno et al., 2021). The statement is relevant to Sanders' statement (Simatupang \& Purnama, 2019) that STEM education does not only develop the content of science, technology, engineering, and mathematics knowledge, but STEM education also fosters critical thinking skills and scientific investigation (Priyatna et al., 2020).

Critical thinking refers to analyzing information to determine the relevance of the information collected and then interpreting it in solving problems (Mutakinati et al., 2018). Furthermore, Lismaya (2019); Plotnikova \& Strukov (2019); Shin et al., (2006) claims that carrying out concept design, application, and information obtained from experience, reflection, observation, and communication as action is included in critical thinking activities. Through critical thinking ability, a person is expected to regulate, adjust, change, or correct their thoughts to make good decisions and act more appropriately (Maulana, 2017). Critical thinking skills can also provide a rational and correct conclusion (Purwati, 2016; Supena et al., 2021).

The developed module is specifically for the material of alternating current (AC) circuits because the students do not 
understand the concept of physics well, especially in the material of alternating current (AC) circuits. According to the students, the alternating current (AC) circuits have too many formulas to memorize, making them think physics is difficult. The process of preparing learning materials must be arranged systematically so that the teaching materials can increase the knowledge and competence of students properly and effectively (Widodo \& Jasmadi, 2008).

Previous research has developed various types of modules, including STEMDiscovery Learning Module (Khotimah et al., 2021), Game-Based STEM Module (Farihah et al., 2021), context-specific modules (O'Neill \& McNamara, 2016). However, the AFKF module is still very rarely developed.

Studies on Resource Package with Physics Events Photo Analysis (AFKF) have been conducted by Sholakhudin (2016) and Rahmah (2017). However, both studies did not contain project development activities. On the other hand, this research contained project development activities to improve students' learning activities. The developed module has been associated with aspects of the STEM approach, which will help students solve problems and provide opportunities for students to understand science combined with technology, engineering, and mathematics through discussion and project creation. The Learning Resource Package developed by Sholakhudin (2016) is based on local wisdom on fluid material, while the AFKF module that the researcher developed is Alternating Current Circuit (AC).

The AFKF module based on the STEM approach makes it easier for students to learn independently. They are led to become problem solvers, inventors, innovators, logical thinkers, and technology literate. Besides, the module that the researcher developed is used to improve the critical thinking skills of high school students. On the other hand, Sholakhudin (2016) research was used to improve students' learning activities, including listening activities, visual activities, writing activities, oral activities, and motor activities. Fika Maulani Rahmah (2017) research was used to examine students' activities and improve high school students' learning outcomes.

Based on the above problems, the main objectives of this study are (1) developing a Physics Event Photo Analysis (AFKF) module based on the STEM approach; (2) determining the effectiveness of the module to improve students' critical thinking skills; (3) determine students' responses to the Physics Event Photo Analysis (AFKF) module based on the STEM approach.

\section{METHODS}

The method used in this research was Research and Development with the ADDIE development model. Research and Development $(\mathrm{R} \& \mathrm{D})$ is a series of processes or steps to develop a new product or improve an existing product to be accounted for (Halim, 2019; Rukun et al., 2019). The ADDIE development model consists of 5 stages: analysis, design, development, implementation, and evaluation, as shown in Figure 1.

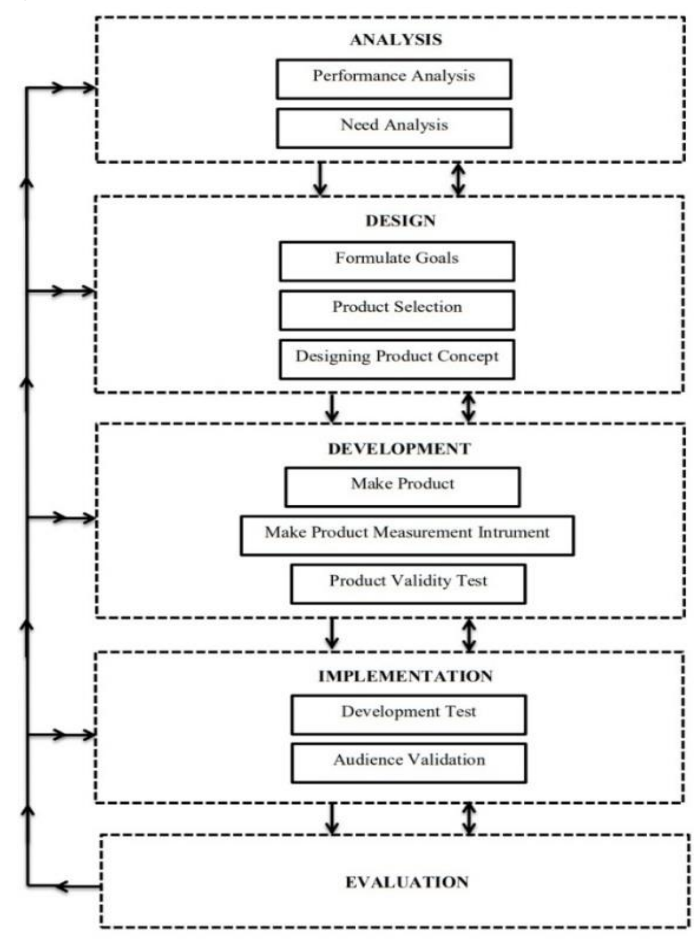

Figure 1. The ADDIE Development Model 
The steps of the ADDIE model used in this development research are (1) analyzing the teaching materials used by the teacher and analyzing the need for teaching materials to be developed; (2) designing the concept of teaching materials according to the characteristics, needs of students, core competencies (KI) and basic competencies (KD), as well as appropriate learning objectives; (3) making teaching materials in the form of modules according to the design, making product measurement instruments, and testing the validity of the products; (4) implementing the STEM approach-based Physics Event Photo Analysis (AFKF) module; and (5) evaluating the results of the products that have been developed.

The data collection techniques used were interviews, product validity, pre-test and post-test, and student response questionnaires. The interviews were used to determine the teaching materials used by the teacher and determine students' characteristics (cognitive, psychomotor, and affective). Product validity was used to determine the feasibility of the product that has been developed. The tests were used to determine the effectiveness of the module to improve students' critical thinking skills. Student response questionnaires were used to determine students' interest in the module that has been developed.

The validators consisted of three validators, namely two expert validators and one user validator. The test was implemented in the second semester of the 2020/2021 academic year at SMA N Rogojampi 1. The subjects of the tests were 26 students in class XII MIPA 3. The research location was determined by the purposive sampling technique, where the target samples were deliberately selected based on characteristics tailored to the needs of the product development. The researcher chose SMA N 1 Rogojampi as the place to implement the development test because the school had never applied the Physics Event Photo Analysis module (AFKF) based on the STEM approach. The development tests were performed within four meetings on the material of alternating current (AC) circuits. The data analysis technique used in this development research was the quantitative descriptive analysis. The results of the validation were analyzed by finding the percentage of validity, which can be formulated as follows (Riduwan, 2015):

$$
P=\frac{f}{N} \times 100 \%
$$

Information :

P: Percentage

F: The obtained scores

$\mathrm{N}$ : Maximum score

The percentages obtained were then categorized into the predicate statements in Table 1 .

Table 1. Validity Criteria

\begin{tabular}{ccc}
\hline No & Percentage & Interpretation \\
\hline 1 & $81 \%-100 \%$ & Very valid \\
\hline 2 & $61 \%-80 \%$ & Valid \\
\hline 3 & $41 \%-60 \%$ & Quite valid \\
\hline 4 & $21 \%-40 \%$ & Invalid \\
\hline 5 & $0 \%-20 \%$ & Very Invalid \\
\hline & & (Sudaryono, 2011)
\end{tabular}

The pre-test and post-test results were analyzed using the $\mathrm{N}$-gain score test for testing the effectiveness of the product, which is formulated as follows.

$$
(g)=\frac{S_{\text {post }}-S_{\text {pre }}}{S_{\text {maks }}-S_{\text {pre }}} \times 100 \%
$$

Information :

$g \quad=$ Normalized gain
$S_{\text {post }}=$ Final test score
$S_{\text {pre }}=$ Initial test score
$S_{\text {maks }}=$ Maximum score

(Hake \& Richard, 2002)

The percentages obtained were then categorized into predicate statements in Table 2.

Table 2. The Criteria for N-gain Test

\begin{tabular}{cc}
\hline N-gain Classification & Criteria \\
\hline$g \geq 70 \%$ & High \\
\hline $30 \% \leq g<70 \%$ & Medium \\
\hline$g<30 \%$ & Low \\
\hline & (Simanjuntak, 2012)
\end{tabular}


The results of the student response questionnaire were analyzed using the following formula.

$$
\begin{array}{r}
\% N R S=\frac{\sum N R S}{N R S \text { Maks }} \\
\times 100 \%
\end{array}
$$

Information :

$\%$ : Parentage of student response scores

$\sum N R S \quad$ : Total student responses scores

NRS Maks : Maximum student responses score

The percentage obtained were categorized into predicate statements in Table 3.

Table 3. Criteria for Questionnaire Percentage

\begin{tabular}{cc}
\hline Interval & Criteria \\
\hline $81,25<N R S \leq 100 \%$ & Very Positive \\
\hline $62,5<N R S \leq 81,25$ & Positive \\
\hline $43,75<N R S \leq 62,5$ & Less Positive \\
\hline $25<N R S \leq 43,75$ & Not Positif \\
\hline & (Ristanti et al., 2019)
\end{tabular}

\section{RESULTS AND DISCUSSION Research Results}

The development product design is shown in Figure 2.

\section{MODUL AFKF BERBASIS}

PENDEKATAN STEM

\section{RANGKAIAN ARUS BOLAK- BALIK (AC)}
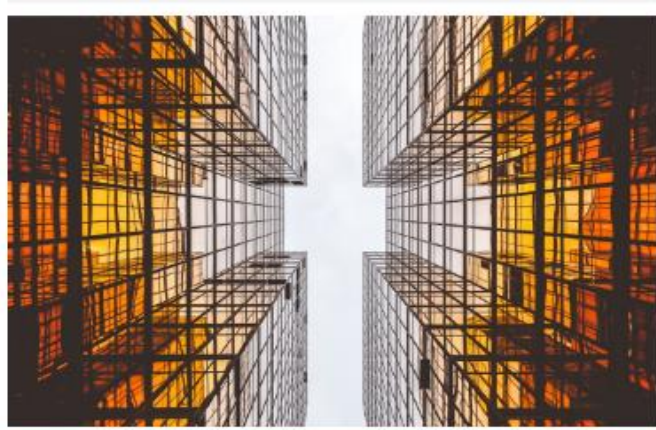

\section{FISIKA}

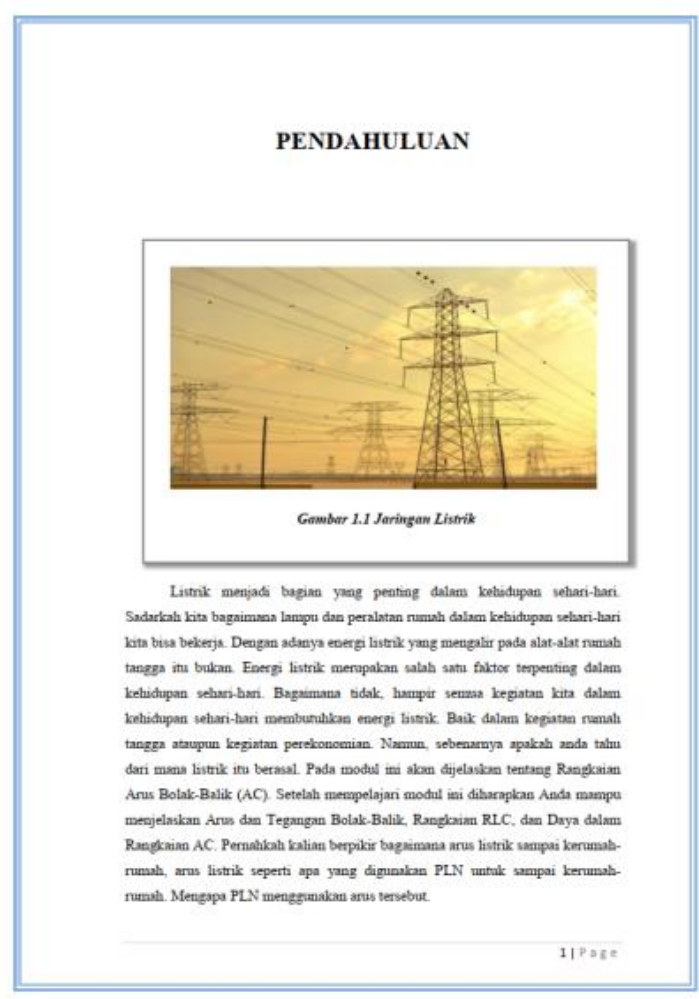

Figure 2. Product Development

The following are the images of product development integrated with the STEM approach is shown in Figure 3.

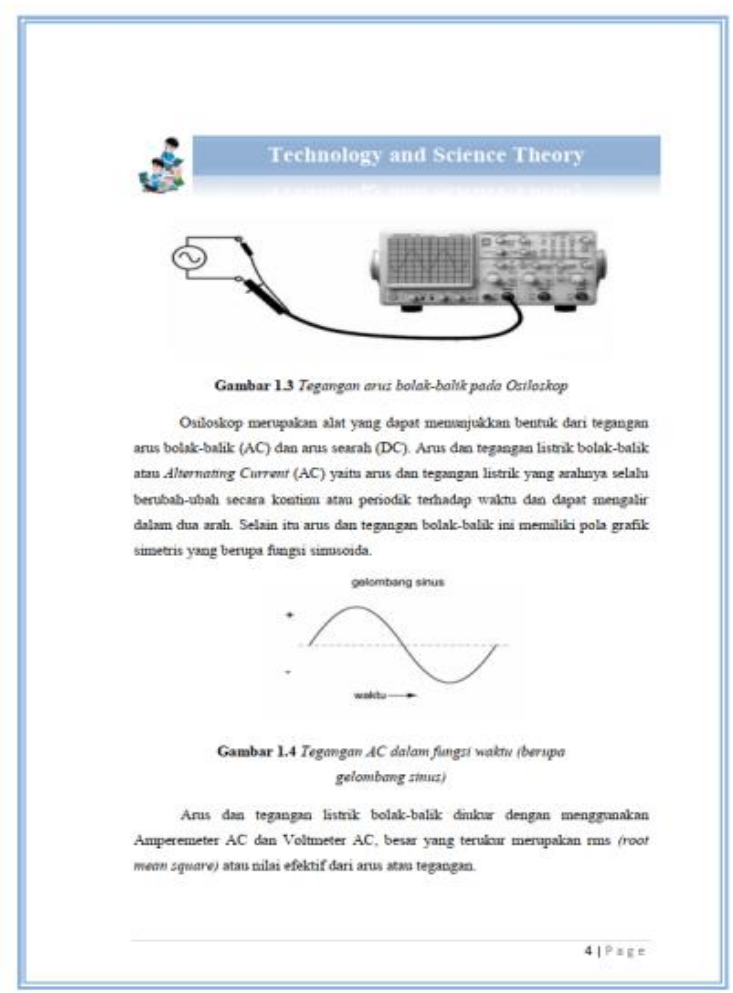

Figure 3.a. Products with the STEM Approach 


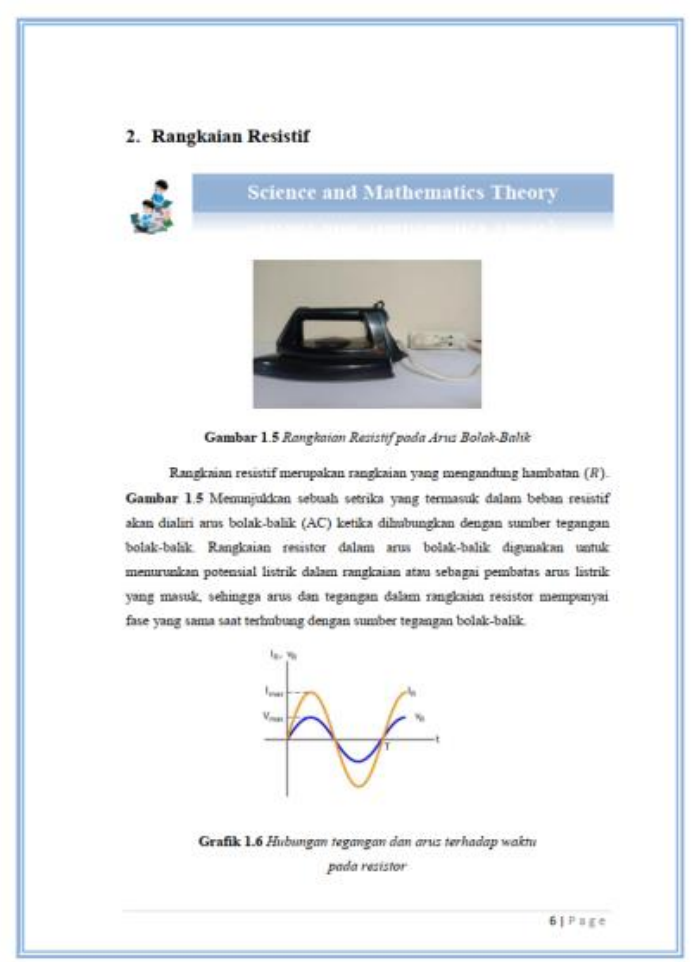

Figure 3.b. Products with the STEM Approach

The product measurement tool was developed in the form of an assessment sheet to measure the feasibility of the product so that it can be implemented in the teaching and learning process and used as an after-learning improvement. The learning process has been developed based on the needs of students.

The module was validated by three validators, namely two expert validators and one user validator. The validation data obtained from the three validators were in the form of quantitative and qualitative data. The quantitative data were in the form of assessment sheets on the feasibility of content, language, presentation, and format. On the other hand, the qualitative data were in the form of criticism and suggestions from the validators so that the product could be more valid.

The quantitative data showed that the validity value was 4.67 , with a validity percentage of $93.4 \%$ in the very valid category (see Table 4). Furthermore, the results obtained from qualitative data indicated that the developed module could be used without revision, shown in table 5 .
Table 4. Quantitative Product Validation

\begin{tabular}{clcl}
\hline No. & Aspect & Value & $\begin{array}{l}\text { Level of } \\
\text { Validity }\end{array}$ \\
\hline 1. & $\begin{array}{l}\text { Feasibility } \\
\text { Content }\end{array}$ & 4,62 & \\
\cline { 1 - 2 } 2. & Languages & 4,74 & \\
\cline { 1 - 2 } 3. & Serving & 4,75 & Very Valid \\
\hline 4. & Format & 4,58 \\
\hline & Average & 4,67 \\
\hline & Percentage & $93,4 \%$ \\
\hline
\end{tabular}

Table 5. Qualitative Products Validation

\begin{tabular}{|c|c|c|}
\hline Validators & $\begin{array}{c}\text { General } \\
\text { Assessment }\end{array}$ & $\begin{array}{l}\text { Critics and } \\
\text { Suggestions }\end{array}$ \\
\hline V1 & $\begin{array}{l}\text { Can be used } \\
\text { without revision }\end{array}$ & $\begin{array}{l}\text { Pay attention to } \\
\text { students' } \\
\text { readiness and } \\
\text { availability of } \\
\text { practical tools in } \\
\text { schools. }\end{array}$ \\
\hline V2 & $\begin{array}{l}\text { Can be used } \\
\text { without revision }\end{array}$ & - \\
\hline V3 & $\begin{array}{l}\text { Can be used } \\
\text { without revision }\end{array}$ & $\begin{array}{l}\text { Student abilities } \\
\text { and the } \\
\text { availability of } \\
\text { tools and } \\
\text { materials at } \\
\text { school. }\end{array}$ \\
\hline
\end{tabular}

Based on the assessment of each aspect, the developed module was declared very valid and can be used without revision.

The development test was conducted to see the effectiveness of the Physics Events Photo Analysis (AFKF) module based on the STEM approach through pre-test and post-test to improve students' critical thinking skills. The development test was conducted at SMA Negeri 1 Rogojampi in class XII MIPA 3 by taking a sample of 26 students. The development tests were conducted in four meetings. The learning models used to implement the product were lectures and discussions. Before the learning was carried out using the STEM approachbased Physics Event Photo Analysis (AFKF) module, a pre-test was conducted to determine the students' abilities regarding the alternating current (AC) circuit material. At the end of the meeting, a post-test was administered to evaluate the effectiveness 
after learning using the developed module. Based on the analysis results using the $\mathrm{N}$ gain formula, there were differences in learning outcomes related to students' critical thinking skills. After the students used the developed modules, there was an increase in learning outcomes related to students' critical thinking, from the initial pre-test score average of 27.04 to an average post-test score of 75.62 with an effectiveness percentage of $66.58 \%$. The values showed that the increase in critical thinking skills was in the moderate category (see table 6).

Table 6. The Results of the Development Tests

\begin{tabular}{lccc}
\hline Component & Pre-Test & Post-Test & Difference \\
\hline Average & 27,04 & 75,62 & \multirow{2}{*}{48,58} \\
\cline { 1 - 3 } High score & 70 & 89 & \\
\hline Low score & 7 & 42 & \\
\hline N-gain (\%) & & $66,58 \%$ & \\
\hline Category & & Medium & \\
\hline
\end{tabular}

Based on the results of the N-gain test, it can be concluded that the STEM approachbased Physics Event Photo Analysis (AFKF) module can be declared effective in improving students' critical thinking skills. Also, the Physics Event Photo Analysis (AFKF) module based on the STEM approach was feasible to be used and distributed to other classes or other schools. The module is included in the characteristics of a good learning module stated by Sitepu (Kustandi \& Darmawan, 2020): (1) it is selfinstructed because the developed module enables students to learn independently. Without the help of the teacher, students can work on the questions in the module correctly. (2) It is self-contained because the developed module is entirely done following the competency unit. The learning material is completely presented so that learning is more effective. (3) It is stand-alone because the developed module does not depend on other media. The students do not find it difficult with other supporting media. (4) It is adaptive because the developed module has high adaptive power to the development of science and technology. The module can adapt to the development of science and technology and is flexible in learning. (5) It is user-friendly because the developed module is easy to operate, easy to understand, and easy to respond to by students. The students can understand the material contained in the module well to affect the consistency of students in learning.

The evaluation was carried out after the development tests ended as a whole. It was used to find out students' responses to the Physics Event Photo Analysis (AFKF) module based on the STEM approach. The evaluation data was obtained from the results of the student response questionnaires after implementing the developed module. Table 7 displays the results of student responses to the Physics Event Photo Analysis module (AFKF) based on the STEM approach.

Table 7. Students' Responses to the Module

\begin{tabular}{ccccc}
\hline No & Aspect & $\mathbf{( \% )}$ & Average & Category \\
\cline { 1 - 3 } 1. & Presentation & $78 \%$ & $76 \%$ & Positive \\
\cline { 1 - 2 } 2. & Effectiveness & $74 \%$ & & \\
\cline { 1 - 2 } 3. & Content & $75 \%$ & & \\
\hline
\end{tabular}

\section{Discussion}

\section{The Validity of the AFKF Module Based on the STEM Approach}

The validity of the AFKF module based on the STEM approach was carried out by three validators, namely two expert lecturers in Physics Education at the University of Jember and one user validation by a physics teacher at SMA Negeri 1 Rogojampi. The expert validation sheets and the user validation sheet contained the same indicators, namely 20 indicators grouped into four aspects. There were seven indicators on the content feasibility, five on the linguistic aspects, four on the presentation aspects, and four on the format aspects.

The content feasibility aspect was used to see the suitability of the module content with Core Competencies (KI), Basic Competencies (KD), learning objectives to 
be achieved, student needs, integration of material with STEM, and the suitability of test questions with the material. Besides, they were also used to see the materials' correctness and the instructions' clarity in the module. The feasibility aspect of the module content obtained scores from the range of 4.33 to 5 . The average score for the linguistic aspect was 4.62, with the percentage of validity being $92 \%$. The percentage results indicated that the feasibility aspect of the module content was included in the very valid category.

The linguistic aspect was used to see whether the language met the feasibility aspect, is easy to understand, follows Indonesian rules, is communicative, and is effective and efficient. The linguistic aspect of the module got a score from the range of 4.67 to 5 . The average score of the linguistic aspect was 4.74, with a percentage of validity of $94 \%$. This percentage showed that the feasibility aspect of the module content was included in the very valid category.

The presentation aspect was used to see that the modules presented have clear objectives, the explanation in the module is coherent from beginning to end, the modules are presented quite interestingly, and have complete information. The presentation aspect of this module got a score from the range of 4.67 to 5 . The average score of the linguistic aspect was 4.75 , with the percentage of validity being $95 \%$. The percentage results indicated that the feasibility aspect of the module content was included in the very valid category.

The format aspect is used to see the font usage, cover appearance, layout, and module design. The format aspect scores 4.33 to 4.67. The average score obtained from the linguistic aspect is 4.58 , with the validity percentage being $92 \%$. This percentage shows that the feasibility aspect of the module content is included in the very valid category.

The results of experts and user validation of the AFKF module based on the STEM approach obtained an overall score of 4.67 with a validity of $93 \%$. The results were adjusted to the category by Sudaryono (2011), where the developed module is categorized as valid if the overall percentage is $81 \%-100 \%$. Based on these results, the AFKF module based on the STEM approach was declared fit for use to be implemented in schools or development test sites.

\section{The Effectiveness of the AFKF Module Based on the STEM Approach}

The physics Event Photo Analysis Module (AFKF) based on the STEM approach was presented by analyzing photos of physics events in everyday life related to the material of alternating current circuits (AC). According to Rachmawati et al. (2017), the activity of analyzing these physics events can be used to trigger students' thinking. In addition, the material in the module is also integrated with the STEM approach because the STEM approach can develop students' critical thinking skills (Lestari et al., 2018). To determine the increase in students' critical thinking skills, the pre-test, and post-test questions had been prepared with indicators of critical thinking skills according to Santoso (2016), which consisted of 6 indicators: interpretation, analysis, inference, explanation, and evaluation, and self-regulation.

The effectiveness of the AFKF module based on the STEM approach was analyzed using quantitative descriptive analysis. The types of tests used were pre-test and posttest. The results of the pre-test and post-test were tested using the $\mathrm{N}$-gain test. The $\mathrm{N}$ gain test was used to determine the effectiveness of the module developed in improving the critical thinking skills of high school students. The questions in the pretest and post-test were relevant to the critical thinking skills indicators. The results obtained indicated an increase from before and after the application of the module. The increase in the $\mathrm{N}$-gain test was classified in the medium category with an average $\mathrm{N}$ - 
gain score of $66.58 \%$. This result showed that the AFKF module based on the STEM approach was effective.

The results of the $\mathrm{N}$-gain test analysis on the pre-test data showed that the students' scores were still low, and no one had reached the criteria of minimum mastery set by SMA Negeri 1 Rogojampi (75). However, the highest scores obtained by students in the limited trial and development tests during the pre-test were 49 and 70. Most students could not solve the questions according to the indicators of critical thinking skills. However, when the post-test was administered, the students' ability was better in answering questions according to the indicators. On the Evaluation indicators, the scores obtained by the students were a little low since they only answered by writing their conclusions without describing the results of their calculations. Besides, the students also did not write down what was known from the question. The results of the $\mathrm{N}$-gain test analysis on the post-test data indicated that the students' scores reached the predetermined completeness criteria. The highest scores obtained by students in the limited trial and development test during the post-test were 78 and 89.

The Physics Event Photo Analysis Module (AFKF) based on the STEM approach was declared effective in improving the critical thinking skills of high school students, shown by an increase in students' critical thinking skills before and after implementing the developed module. The module developed was directed to analyze photos of physics events in everyday life related to the material because, according to Rachmawati et al. (2017), activities to analyze physics events are needed to trigger students' thinking skills. Furthermore, the material in this developed module had been integrated with the STEM (Science, Technology, Engineering, and Mathematics) approach. Based on the theory stated by Lestari et al. (2018), the STEM approach in learning enables students to acquire deeper knowledge and makes students more skilled in dealing with reallife problems in everyday life and developing students' critical thinking skills.

\section{Students' Responses to the AFKF Module Based on the STEM Approach}

The response questionnaire was used to determine students' responses to the Physics Event Photo Analysis (AFKF) module based on the STEM approach. In general, students answered that they agreed with the statement given, and the rest answered that they strongly agreed and even disagreed. The student response questionnaire consisted of ten statements which can be grouped into three aspects. The aspects of the student response questionnaire include three indicators on the presentation aspects, four indicators on the effectiveness aspects, and three indicators on the content aspects.

The presentation aspects were used to see students' interest in the module, the language used, and the motivation to learn physics. The value of the average percentage of students' responses toward the development test for the presentation aspect was $78 \%$. The results showed that students showed positive responses toward the developed module.

The aspect of effectiveness was used to see that with the module, the physics learning becomes less boring, students become motivated to learn independently, students who have no difficulty working on physics problems, and students who become more courageous in expressing their opinions. The average percentage of students' responses to the aspect of effectiveness was $74 \%$. The results showed that students showed positive responses to the developed module.

The aspect of effectiveness was used to see that through the module, the students understand physics concepts, understand the application of physics in everyday life, and help students master the material. The average percentage of students' responses to the aspect was $72 \%$. The results showed that 
students showed positive responses to the developed module.

The overall student response questionnaire analysis using the Likert scale showed that the percentage of the student's response score was $69 \%$ towards the use of the developed module. It showed that students responded positively to using the Physics Event Photo Analysis (AFKF) module based on the STEM approach.

The module received positive responses from the students because the module had been arranged systematically with easy-tounderstand wording. The module was arranged according to the steps for compiling modules according to Sudjana and Rivai (Sani, 2015), namely (1) preparation of a framework which contains learning objectives, evaluation questions, learning materials, tools needed in activities learning in the module, (2) writing the program in detail, which consists of teacher instructions, student activity sheets, student worksheets, test sheets, and test answer sheets.

The advantages of the Physics Event Photo Analysis Module (AFKF) based on the STEM approach (Science, Technology, Engineering, and Mathematics) is one of the printed teaching materials that are arranged systematically and attractively according to $\mathrm{KI}$, KD, and learning objectives to be achieved. The module had been compiled with photos of physics events related to the alternating current (AC) circuit material, which students will later analyze with questions about the photos of physics events. Besides, the student activities and in each learning material contained had been integrated with the STEM approach because the STEM approach can improve students' critical thinking skills. Lestari et al. (2018) state that the STEM approach develops students' critical thinking skills and allows students to gain deeper knowledge. Sukmana (2018) states that the STEM approach in learning affects improving students' critical thinking skills.
Another similar research was conducted by Sholakhudin (2016) with the title Learning Resource Package (PSB) with Photo Analysis of Physics Events (AFKF) based on local wisdom in physics learning at SMK. The similarity lies in the physics Event Photo Analysis (AFKF). This research showed that through the Physics Event Photo Analysis (AFKF), the students' learning outcomes in the cognitive and affective domains can be categorized as moderate. This result showed that the physics Event Photo Analysis (AFKF) effectively improved students' learning outcomes. Also, students gave positive responses toward the product.

\section{CONCLUSIONS AND SUGGESTIONS Conclusions}

In product development research of the Physics Event Photo Analysis (AFKF) module based on the STEM approach, it can be concluded that the developed module was feasible to use to be implemented at the development tests. The module developed was declared effective in improving the critical thinking skills of high school students, and the students also responded positively to learning using the module. The Physics Event Photo Analysis Module (AFKF) based on the STEM approach also has an important role in the pedagogical aspect. Using the STEM approach will make students become creative and imaginative scientists, students can solve problems, and make students mathematically and technologically literate. Also, by learning STEM, the students learn everything relevant and contextual to everyday life.

\section{Suggestion}

Based on the research, some suggestions for the next researchers are provided: (1) time management should be considered to avoid reducing the learning time. (2) The AFKF module based on the STEM approach can then be tested in several different schools with different subjects to determine its effectiveness in more detail. 


\section{ACKNOWLEDGMENT}

The researchers would like to express their gratitude to the Lecturer in Physics Education Research, Faculty of Teacher Training and Education, the University of Jember, who has provided the opportunity for researchers to conduct research and has provided a lot of assistance through discussions in the implementation of this research.

\section{REFERENCES}

Ardianti, S., Sulisworo, D., Pramudya, Y., \& Raharjo, W. (2020). The impact of the use of STEM education approach on the blended learning to improve student's critical thinking skills. Universal Journal of Educational Research, 8(3B), 24-32. https://doi.org/10.13189/ujer.2020.0 81503

Broman, K., Bernholt, S., \& Parchmann, I. (2018). Using model-based scaffolds to support students solving contextbased chemistry problems. International Journal of Science Education, 40(10), 1176-1197. https://doi.org/10.1080/09500693.20 18.1470350

Budi, A. P. S., Sunarno, W., \& Sugiyarto. (2018). Natural science modules with SETS approach to improve students' critical thinking ability. Journal of Physics: Conference Series, $\quad 1022, \quad 012015$. https://doi.org/10.1088/17426596/1022/1/012015

Darma, R. S., Setyadi, A., Wilujeng, I., Jumadi, \& Kuswanto, H. (2019). Multimedia learning module development based on SIGIL software in physics learning. Journal of Physics: Conference Series, 1233, 012042.

https://doi.org/10.1088/17426596/1233/1/012042

Fajarini, A. 2018. Membongkar rahasia pengembangan bahan ajar IPS. IAIN Jember.
Farihah, M. J., Norawi, A. M., \& Jahan, A. N. (2021). Game-based STEM module development for KSSM science teachers. Journal of Turkish Science Education, 18(2), 249-262. https://doi.org/10.36681/tused.2021. 63

Fouryza, D., Amin, S. M., \& Ekawati, R. (2019). Designing lesson plan of integer number operation based on fun and easy math (FEM) approach. International Journal of Evaluation and Research in Education, 8(1), 103-109.

Hake, R. R. (2002). Relationship of individual student normalized learning gains in mecahnics with gender, high-school physics, and pretest scores on mathematics and spatial visualization. The Physics Education Research Conference: 114.

Halim, H., \& Haidir, H. (2019). Penelitian pendidikan. Kencana

Hidayati, T. (2018). Pengembangan perangkat pembelajaran matematika dengan suplemen history of mathematics. Pena Persada.

Jeong, H.-S., \& Park, J.-W. (2011). Practical suggestions for the effective use of everyday context in teaching physics -based on the analysis of students' learning processes. Journal of The Korean Association for Science Education, 31(7), 1025-1039. https://doi.org/10.14697/jkase.2011. 31.7.1025

Khotimah, R. P., Ahmad, C. N. C., Adnan, M., \& Murtiyasa, B. (2021). The development of STEM-discovery learning module in differential equations: A need analysis. Review of International Geographical Education Online, 11(4), 941-950. https://doi.org/10.33403/rigeo.80068 08

Kustandi, C., \& Darmawan, D. (2020). Pengembangan media pembelajaran. Kencana. 
Lestari, D. A. B., Astuti, B., \& Darsono, T. (2018). Implementasi LKS dengan pendekatan STEM (science, technology, engineering, and mathematics) untuk meningkatkan kemampuan berpikir kritis siswa. Jurnal Pendidikan Fisika Dan Teknologi, $\quad 4(2), \quad 202$. https://doi.org/10.29303/jpft.v4i2.80 9

Lestari, T. P., \& Sumarti, S. S. (2018). STEM-based project based learning model to increase science process and creative thinking skills of 5th grade. Journal of Primary Education, 7(1), 18-24.

Lin, Y. Y., Holmqvist, K., Miyoshi, K., \& Ashida, H. (2017). Effects of detailed illustrations on science learning: An eye-tracking study. Instructional Science, 45(5), 557581. https://doi.org/10.1007/s11251017-9417-1

Lou, S. J., Chou, Y. C., Shih, R. C., \& Chung, C. C. (2017). A study of creativity in $\mathrm{CaC} 2$ steamshipderived STEM project-based learning. Eurasia Journal of Mathematics, Science and Technology Education, 13(6), 23872404.

https://doi.org/10.12973/EURASIA. 2017.01231A

Maison, \& Wahyuni, I. (2021). Guide inquiry science e-module development for improving junior high school students' scientific literacy. Journal of Physics: Conference Series, 1876(1), 012089. https://doi.org/10.1088/17426596/1876/1/012089

Melvinasari, \& Suparman. (2019). Design of mathematics module based on RME to improving the problem-solving ability. International Journal of Scientific and Technology Research, 8(11), 3918-3922.

Mutakinati, L., Anwari, I., \& Yoshisuke, K. (2018). Analysis of students' critical thinking skill of middle school through STEM education projectbased learning. Jurnal Pendidikan IPA Indonesia, 7(1), 54-65. https://doi.org/10.15294/jpii.v7i1.10 495

O’Neill, G., \& McNamara, M. (2016). Passing the baton: A collaborative approach to development and implementation of context-specific modules for graduate teaching assistants in cognate disciplines. Innovations in Education and Teaching International, 53(6), 570580.

https://doi.org/10.1080/14703297.20 15.1020825

Pane, A. N., Andra, D., \& Wayan Distrik, I. (2021). The development physics emodule based PBL-Integrated STEM to improve higher-order thinking skills on static fluid material. Journal of Physics: Conference Series, 1796(1), 012086. https://doi.org/10.1088/17426596/1796/1/012086

Parno, Supriana, E., Widarti, A. N., \& Ali, M. (2021). The effectiveness of STEM approach on students' critical thinking ability in the topic of fluid statics. Journal of Physics: Conference Series, 1882(1), 012150. https://doi.org/10.1088/17426596/1882/1/012150

Plotnikova, N. F., \& Strukov, E. N. (2019). Integration of teamwork and critical thinking skills in the process of teaching students. Cypriot Journal of Educational Sciences, 14(1), 1-10.

Priyatna, N., Lorenzia, S. A., \& Widodo, S. A. (2020). STEM education at junior high school mathematics course for improving the mathematical critical thinking skills. Journal for the Education of Gifted Young Scientists, $8(3)$, 1173-1184. https://doi.org/10.17478/jegys.72820 9 
Purwati, R., Hobri, dan Fatahillah, A. (2016). Analisis kemampuan berpikir kritis siswa dalam menyelesaikan masalah persamaan pada pembelajaran model creative problem solving. Jurnal Pendidikan Matematika, 7(1), 84-93.

Rachmawati, I. N., Gani, A. G., \& Indrawati. (2017). Implementasi model pembelajaran proyek (project based learning) dengan analisis kejadian fisika dalam pembelajaran fisika di SMA. Jurnal Pembelajaran Fisika, 6(2), 183-185.

Rahmah, F. M., Sutarto, \& Mahardika, I. K. (2017). Paket sumber belajar (PSB) dengan analisis foto kejadian fisika (AFKF) pada materi usaha energi. Seminar Nasional Pendidikan Fisika 2017, 2(1) 1-5.

Riduwan. (2015). Skala pengukuran variabel-variabel penelitian. Alfabeta

Ristanti, V. N. D., Nurmilawati, M., \& Sulistiyowati, T. I. (2019). Respon siswa terhadap modul pembelajaran berbasis SAVI (somatic, auditory, visualitation, intelegency) pada materi ekosistem di SMAN 1 Papar. Jurnal Biologi dan Pembelajarannya, 6(1), 36-38.

Riyana, C. (2012). Media pembelajaran. Kementrian Agama RI.

Rufaida, S., \& Nurfadilah, N. (2021). The effectiveness of hypercontent module to improve creative thinking skills of prospective physics teachers. Journal of Physics: Conference Series, 1918(2), 022022. https://doi.org/10.1088/17426596/1918/2/022022

Rukun, K., Permatasari, R. D. P., \& Hayadi, B. H. (2019). Development of digital information management learning media based on adobe flash in grade $\mathrm{X}$ of digital simulation subject. Journal of Physics: Conference Series, 1363(1), 12066.
Sani, M. (2015). Pengembangan modul pembelajaran berbasis proyek pada mata kuliah pembeliharaan dan perbaikan mesin listrik di jurusan teknik elektro universitas negeri surabaya. Jurnal Pendidikan Teknik Elektro. 4(1), 259-267.

Santoso, W. M. (2016). Ilmu sosial: Perkembangan dan tantangan di indonesia. Yayasan Pustaka Obor Indonesia.

Sari, N.T., Sutarto, \& Subiki. (2017). Pengembangan modul berbasis gambar kejadian riil untuk pembelajaran fisika SMA. Jurnal Pembelajaran Fisika, 6(1), 8-19.

Shin, K. R., Lee, J. H., Ha, J. Y., \& Kim, K. H. (2006). Critical thinking dispositions in baccalaureate nursing students. Journal of Advanced Nursing, $\quad 56(2), \quad 182-189$. https://doi.org/10.1111/j.13652648.2006.03995.x

Sholakhudin, M. N., Sutarto, S., \& Subiki, S. (2016). Paket sumber belajar (PSB) dengan analisis foto kejadian fisika (AFKF) berbasis kearifan lokal pada pembelajaran fisika di SMK. Jurnal Pembelajaran Fisika. 5(3), 253-260.

Simanjuntak, M. P. (2012). Peningkatan pemahaman konsep fisika mahasiswa melalui pendekatan pembelajaran pemecahan masalah berbasis video. Jurnal Pendidikan Fisika, 1(2), 55-60.

Simarmata, J., Simanihuruk, L., Ramadhani, R., Safitri, M., Wahyuni, D., \& Iskandar, A. (2020). Pembelajaran STEM berbasis HOTS. Yayasan Kita Menulis.

Simatupang, H., \& Purnama, D. (2019). Handbook best practice strategi belajar mengajar. Pustaka Media Guru.

Suardi, M. (2018). Belajar dan Pembelajaran. Deepublish.

Sudaryono, S. Guritno, \& U. Raharjo. (2011). Theory and aplication of it 
research: Metodologi penelitian teknologi informasi. Andi Offset.

Sukmana, R. W. (2018). Implementasi pendekatan STEM (science, technology, engineering, and mathematics) untuk meningkatkan keterampilan berpikir kritis siswa sekolah dasar. Primaria Educationen Journal, 1(2), 113-119.

Sung, H.-Y., Hwang, G.-J., Chen, C.-Y., \& Liu, W.-X. (2019). A contextual learning model for developing interactive e-books to improve students' performances of learning the analects of confucius. Interactive Learning Environments, 1-14. https://doi.org/10.1080/10494820.20 19.1664595

Supena, I., Darmuki, A., \& Hariyadi, A. (2021). The Influence of 4C (constructive, critical, creativity, collaborative) learning model on students' learning outcomes. International Journal of Instruction, 14(3), 873-892.

Susilana, R., \& Riyana, C. (2009). Media pembelajaran. CV Wahana Prima.

Tapingkae, P., Panjaburee, P., Hwang, G.-J., \& Srisawasdi, N. (2020). Effects of a formative assessment-based contextual gaming approach on students' digital citizenship behaviours, learning motivations, and perceptions. Computers \& Education, 159, 103998. https://doi.org/10.1016/j.compedu.20 20.103998

Triyono, S. (2021). Dinamika penyusunan emodul. Indramayu: CV. Adanu Abimata.

Widodo, C. S., dan Jasmadi. (2008). Panduan menyusun bahan ajar berbasis kompetensi. PT Elex Media Komputindo. 